\title{
Access, equity and social cohesion: evaluation of intersectoral strategies for people experiencing homelessness*
}

\author{
ACESSO, EQUIDADE E COESÃO SOCIAL: AVALIAÇÃO DE ESTRATÉGIAS \\ INTERSETORIAIS PARA A POPULAÇÃO EM SITUAÇÃO DE RUA
}

\section{ACCESO, EQUIDAD Y COHESIÓN SOCIAL: EVALUACIÓN DE ESTRATEGIAS INTERSECTORIALES PARA LA POBLACIÓN EN SITUACIÓN DE CALLE}

Igor da Costa Borysow ${ }^{1}$, Juarez Pereira Furtado²

\begin{abstract}
Objective: To understand and evaluate the work of intersectoral assistance on the insertion and the flow of people in situation of street with severe mental illness in public services of Mental Health. Method: A case study developed from ten visits to a night shelter between March and April 2012. For data collection, the participant observation and semi-structured interviews were carried out with four sheltered individuals, as well as non-directive group interviews with five technicians of the social-assistance services. Results: Were analyzed using Content Analysis and developing a Logic Model validated with the professionals involved. Conclusion: The social assistance services are the main entry of this clientele in the public network of assistance services, and the Mental Health services have difficulty in responding to the specificities of the same clientele and in establishing intersectoral work.
\end{abstract}

\section{DESCRIPTORS}

Homeless persons

Mental disorders

Social Assistance

Intersectorial action

Mental Health Services

Health evaluation

\section{RESUMO}

Objetivo: Compreender e avaliar o trabalho de assistência intersetorial sobre a inserção e o fluxo de pessoas em situação de rua, com transtorno mental grave, nos serviços públicos de Saúde Mental. Método: Estudo de caso, desenvolvido a partir de 10 visitas a um albergue, entre março e abril de 2012. Para a coleta de dados foi realizada a observação participante e entrevistas semiestruturadas com quatro albergados, além de entrevistas não diretivas em grupo, com cinco técnicos dos serviços socioassistenciais. Resultados: Foram analisados por meio da Análise de Conteúdo e da elaboração de Modelo Lógico, e validados junto aos profissionais envolvidos. Conclusão: Os serviços socioassistenciais são a principal entrada dessa clientela à rede pública de assistência, e que os serviços de Saúde Mental apresentam dificuldades em responder às especificidades dessa mesma clientela e estabelecer trabalho intersetorial.

\section{RESUMEN}

Objetivo: Comprender y evaluar el trabajo de asistencia intersectorial acerca de la inserción y el flujo de personas en situación de calle, con trastorno mental severo, en los servicios públicos de Salud Mental. Método: Estudio de caso, desarrollado a partir de 10 visitas a un albergue, entre marzo y abril de 2012. Para la recolección de datos fue realizada la observación participante y entrevistas semiestructuradas con cuatro albergados, además de entrevistas no directivas en grupo, con cinco técnicos de los servicios socioasistenciales. Resultados: Fueron validados mediante el Análisis de Contenido y la confección del Modelo Lógico, y validados junto a los profesionales involucrados. Conclusión: Los servicios socioasistenciales son la principal forma de ingreso de esa clientela a la red pública de asistencia, y que los servicios de Salud Mental presentan dificultades de responder a las especificidades de dicha clientela y establecer trabajo intersectorial.

\section{DESCRIPTORES \\ Personas sin hogar \\ Trastornos mentales \\ Asistencia Social \\ Acción intersectorial \\ Servicios de Salud Mental \\ Evaluación en salud}

\footnotetext{
* Taken from the dissertation "Access and equity: evaluation of intersectoral strategies for people experiencing homelessness with severe mental disorder",

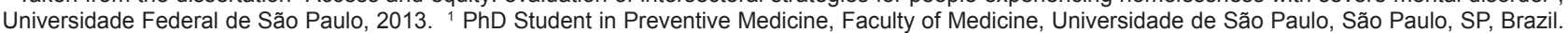
2 Professor, PhD, Head of Department of Public Policies and Collective Health, Universidade Federal de São Paulo, São Paulo, SP, Brazil. 


\section{INTRODUCTION}

In the 1970s, studies have identified an increase of unemployed people living on public streets as a result of disruption of the labor market in Brazil ${ }^{(1-2)}$, and rescued by religious and philanthropic institutions. Initially called street sufferers by the Street Pastoral of the Catholic Church, they were characterized as street people or homeless by the assistance network in the 90s. Under these designations are heterogeneous groups of people living or sleeping in local public, or institutions for the homeless for different reasons, and there may be other causes beyond unemployment(2). More recently, the term people experiencing homelessness started to be used to classify the group that (...) makes the streets their main space of survival and organization of their identities (...) establishing in the public space of the streets the scenario of their private relationships'(3), which can be permanent or transient ${ }^{(4)}$.

In 2008, was presented the National Policy for Social Inclusion of the Population in Situation of Street by the federal government, developed by seven ministries and various social movements ${ }^{(3)}$, articulating different sectors in the care of this social group. The Unified Social Assistance System (SUAS - Sistema Único de Assistência Social), through services contained at the levels of Special Protection of medium and high complexity ${ }^{(5)}$, established different services to meet the specific problems of these clients. In 2012, within the Unified Health System (SUS - Sistema Único de Saúde) was proposed the strategy called Street Office (in Portuguese, Consultório na Rua), linked to primary care to meet the specific needs of this population ${ }^{(6)}$

In the context of these new initiatives, we must consider that people experiencing homelessness have significant prevalence of severe mental disorders ${ }^{(7)}$, constituting challenge to the psychosocial care networks - especially the Centers for Psychosocial Care (CAPS - Centros de Atenção Psicossocial) and the Therapeutic Residential Services (SRT - Serviços Residenciais Terapêuticos) - and the Primary Care. Severe mental illness (SMI) is treated here as cases of functional psychosis that according to the tenth edition of the International Classification of Diseases (ICD$10)^{(8)}$, would be related to degrees of schizophrenia, induced delusional disorder, schizoaffective disorders, nonorganic psychotic disorders, manic episodes and bipolar affective disorder, including major depressive episodes with or without psychotic symptoms. Such disorders have in common a duration of more than two years and the fact of generating psychological and social disabilities that affect the productive and affective capacity and autonomy of affected people, and are aggravated when associated with poverty ${ }^{(8)}$.

The intersectoral integration is a central element in the reform of the Brazilian social protection system, which is considered critical to the success of assistance to people experiencing homelessness, and recurrent in the history of approach plans to this clientele ${ }^{(9)}$. It is also a consensus that guides discussions and at the same time, a major challenge to be implemented into the operational plan. The joining of different sectors of the state to address a social problem requires that the object is recreated from this new and multiple perspective when the objective is to develop integrated actions ${ }^{(10)}$. The intersectionality requires connections between sectors and agencies (governmental or otherwise) to solve social problems of great complexity ${ }^{(9-10)}$. This concept gained visibility in the 1970s, from the debates on health promotion, when various sectors were made responsible for the pursuit of equity ${ }^{(10)}$. However, there are difficulties in establishing intersectoral actions, including among Ministries responsible for Social Security ${ }^{(9)}$.

The intersectoral work is of particular importance when it comes to effectively responding to the needs of people experiencing homelessness with severe mental illness, in which the complexity significantly surpasses the capacity of a single sector. However, in the practice of services linked to each of the two mentioned sectors, arise key issues that hinder collaborative actions. For example, the workers of Mental Health services may have reservations about the homeless, seen as having predominantly social issues and therefore, subject of care related to the SUAS ${ }^{(11)}$. On its turn, the user embracement of individuals in serious mental distress in social assistance services may be perceived as particularly burdensome for workers little or not familiar with the subjective, individual and social determinants involved in these situations ${ }^{(12)}$.

Based on the exposed, was carried out a case study on the care to people experiencing homelessness with SMI, in order to understand and evaluate the factors that influence the success and failure of intersectoral work done by services linked to the SUS and SUAS with this clientele. Thus, will be identified the main issues permeating the assistance offered by the Health sector when required by the Social Assistance, through Mental Health assistance for users of a night shelter linked to the SUAS.

\section{METHOD}

The case study was defined as all flows established between a municipal night shelter and a CAPS unit in the assistance to people experiencing homelessness with SMI. It is located in a city in the interior of the state of São Paulo with 290,000 inhabitants (data from the Brazilian Institute of Geography and Statistics), and positioned just below the first five hundred districts in Brazil according to the human development index (HDI). The city chosen for the study develops actions of Social Assistance through four Reference Centers for Social Assistance (CRAS), a Center of Specialized Reference in Social Assistance (CREAS), a Center of Specialized Reference in Social Assistance for the homeless (CREAS-POP) and two Temporary Care Institutions (child and adult night shelter). The Network of Mental Health consists of a CAPS III (which operates 24 
hours/day), a CAPS II (daytime operation), a CAPS AD (for treatment of addiction to alcohol and other drugs) and CAPS-child. The network of primary care has ten units of Family Health (USAFA).

The case study allowed the consideration of particularities and in-depth analysis of the interactions between sectors problematized in the previous topic ${ }^{(13)}$. For data collection was used the participant observation ${ }^{(14)}$ by inserting the lead researcher in the public night shelter in 10 visits over five weeks, each one lasting approximately the period of a morning or an afternoon. In addition, semistructured interviews were conducted with each of the monitored subjects, three women and a man, identified here in under fictitious names. They had in common the fact of being simultaneously users of the night shelter and having a potential demand of care by the CAPS teams. In order to capture the perceptions of workers, two nondirective interviews were conducted in groups ${ }^{(15)}$. Three technicians participated in the first group (a social educator from CREAS, a social worker from the night shelter and a social assistant from the CREAS-POP), and two other technicians participated in the second group (an educator from the Social Approach and a social worker from the CREAS-POP). The participant observation and individual and group interviews were conducted in the period between March and April 2012. A logical model was developed based on the field work $^{(13)}$, graphically representing how are supposed to operate the user embracement and the assistance to people experiencing homelessness by the two sectors considered here (Figure 1). Partial results were discussed with the members of the groups of nondirective interviews, allowing the validation of the findings and the survey of new information and issues.

Data were initially processed through the program NVivo 9. The Content Analysis ${ }^{(16)}$ was used to categorize the information generated according to the references of our interest around the axes of analysis: accessibility ${ }^{(17)}$; equity ${ }^{(18)}$ and disaffiliation ${ }^{(19)}$. Accessibility refers to the adjustment between the resources available in the assistance network and the community needs, which distinguishes from access that refers to the ability of agents to seek and use health care. The ecological (location), organizational (difficulties to enter the system, internal service matters) or financial (cost of services) barriers may hinder the accessibility ${ }^{(17)}$. In a critical study about equity, the authors concluded that the term refers to the product of social policies invested in the different treatments of particularly vulnerable subjects, in order to overcome injustices arising from social inequality ${ }^{(18)}$.

The areas of social cohesion, integration, vulnerability, assistance and disaffiliation, provide limits of social inclusion and are organized by the society, institutions and the state ${ }^{(19)}$. Instability at work, in family and/or community relations are socially located in the vulnerability zone. When these have links with society through social services, they enter the assistance zone ${ }^{(19)}$. If there is disruption to the labor market and the social ties are highly unstructured, they become part of the zone of disaffiliation.

The study was approved by the Bioethics Committee of the Universidade Federal de São Paulo, under number 1891/11, and by the department of Social Assistance of the investigated municipality.

\section{RESULTS}

The discussion of the logical model allowed establishing the differences between the planning (Figure 1) and what was actually put into practice by the sectors involved in the care of homeless with SMI in the city.

people experiencing homelessness with SMI without user embracement
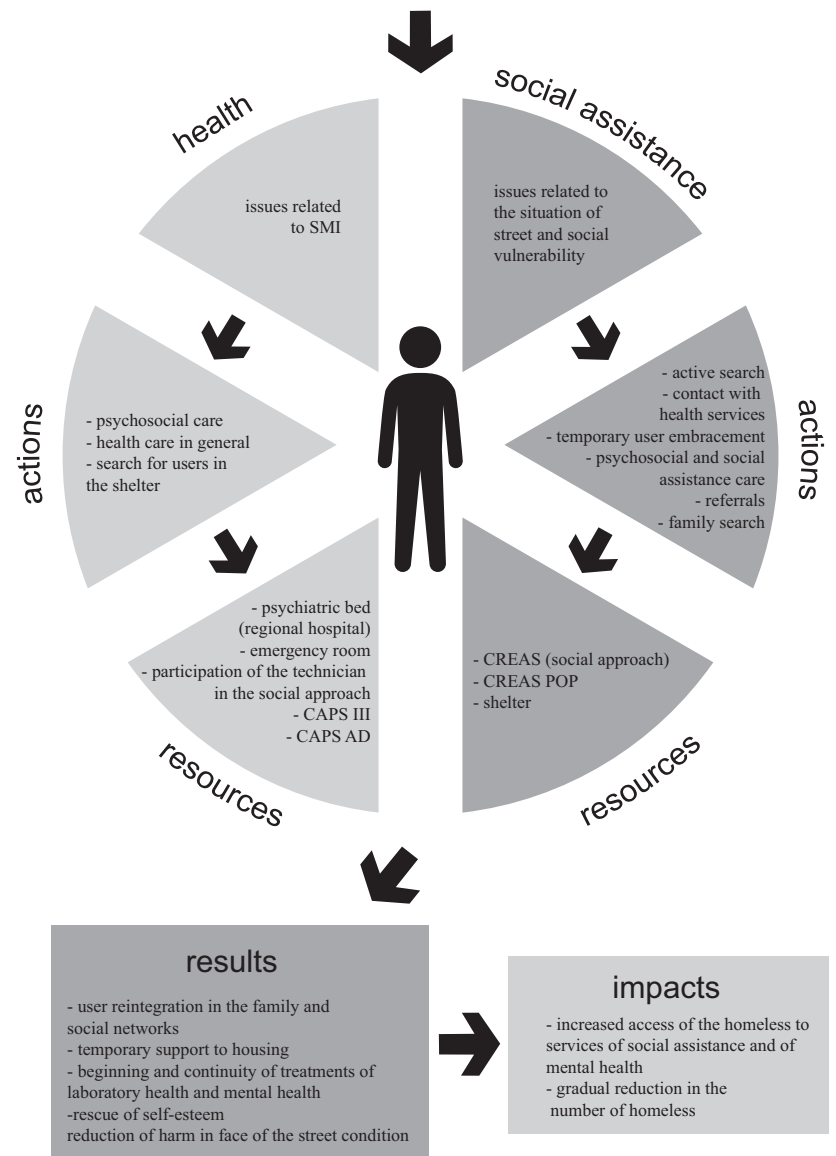

Figure 1- Logical model of the network of services and activities of the itinerary of people experiencing homelessness in the county, developed with the interviewed technicians.

The model above shows the lack of strategies in the health sector for an active search, highlighting the absence of the Family Health Strategy, that is restricted to Social Assistance through the service of street approach. The support given by the county service of Mental Health is provided with psychosocial care offered a period per week, on Tuesdays afternoon, by an occupational 
therapist at CAPS. Additionally, a vehicle of the Municipal Health Secretariat ensures daily shuttles to CAPS for the night shelter users.

The strategy of Street Approach has been the most common form of access of the homeless to municipal public services, and the presence of the occupational therapist in these actions contributes with identifying the needs of the homeless with SMI. However, the social assistance team, when unaccompanied by the occupational therapist, showed visible insecurity in face of the cases that required the skilled eye of Mental Health, especially in crisis situations. This feeling of helplessness is magnified with the frequent difficulty of the teams from Mobile Emergency Services (SAMU - Serviço de Atendimento Móvel de Urgência) to prioritize assistance requests made by the social assistance teams. There was a reported situation, in which SAMU professionals and the Municipal Guard, attending an emergency, refused to carry out an intervention with a homeless person presenting a confused and aggressive state, until the arrival of the social assistance team, considered by them as responsible for the case.

We also observed the work of the action called Dignity Operation, of the Public Security Bureau of the city, run by the Municipal Guard at nights prior to holidays and weekends, usually in the summer season. After initially approaching the people experiencing homelessness, the team issued a police certificate and took them to the night shelter. A street-cleaning company participated in this action in coordination, by cleaning the area with water jets as soon as the homeless were removed.

This approach to people experiencing homelessness held by the public security sector and not coordinated with social assistance services, turns the act of sending to the night shelter an indiscriminate act, with consequences for the homeless and the overcrowding of the service. As reported by one of the interviewed professionals:

There are garbage pickers who go out to do recycling (...) and they end up drinking (...), sleep under a porch and come back the following morning. In case there is a Dignity Operation, everybody goes to the night shelter, do you know what I mean? (T2).

The interviewed workers made explicit criticisms to the Dignity Operation, given its instrumental character of physically removing people from the streets without taking other factors involved into consideration, and the effects of their connection with the night shelter workers. Another critical issue pointed out by professionals are the requests from the community demanding that the night shelter staff remove the homeless from certain areas of the city, usually near the homes or workplaces of requesters.

It was found that the location of the night shelter is far from commercial city areas where most of the homeless are concentrated. The interviewed group criticized the new installation of CREAS-POP that was implemented in this address due to community resistance against its location in the central region:

The population mobilizes because they do not want homeless people near their house, close to their work (T1).

Besides the distant location from where the clientele actually lives and moves, both the night shelter as the CREAS-POP are installed in a region considered violent and devoid of leisure options. Accompanied women, users of the night shelter said they do not usually leave the premises because of fear:

Mate, I dont like to come alone (...) I go out but Im afraid (Aline).

The CAPS III and CAPS AD have not developed strategies aimed at people on the streets, except for the presence of occupational therapists in the aforementioned social approach, leading the social assistance staff to assume responsibilities that could be shared with the Health sector. By abandoning the CAPS treatment, the rehabilitation is done through the Social assistance, since the user can return spontaneously or be arbitrarily brought to the night shelter again. As reported by the technician:

He returns to the assistance because when he's on the street, the homeless population in our county is of assistance, got it? (T2).

The CAPS defined for assisting the chemically dependent (CAPS-AD) conducted visits and meetings at the night shelter, although discontinuously, which was justified by the shortage of staff available for that service, considering the high number of people outside in need of that type of care. In addition to these reported difficulties with conducting collaborative assistance with the CAPS-AD in cases of addiction presented by the homeless in the night shelter, there are intersubjective difficulties presented by the social assistance team itself, with the user embracement of the chemically dependent in the night shelter.

In the emergency room and hospital, when the homeless are identified as such, they are usually routed to the night shelter without receiving treatment, with the justification that they should go through social services first (registration, bath, etc), as a condition for using these services. For the interviewed workers, the fact that this clientele shows up dirty and/or drunk justifies the rejection by hospitals and other health services, situations mitigated only by the intervention of professionals from one of the two sectors involved. Even with regard to procedures between services and sectors for people experiencing homelessness, it is seen that the flow is ensured through personal connections:

Oh you know someone, then, you can ring them can you do me a favor? (T2).

In the absence of the mentioned CAPS technique, there were difficulties in sharing cases with other service professionals, in addition to problems with scheduling 
appointments for the homeless. The need to legitimize the intersectoral and interservice performance with stable flows was pointed out:

Service protocol (...) the CREAS works together with the night shelter, with the CAPS, with the CREAS-POP, there has to be an agreement among equipments, not only with people, said the technician (T1).

When the CAPS technician went on vacation, the social assistance team had difficulties in the dialogue with this service. The interviewed workers understand that the network is formed by people, and if people leave the services, the network stops functioning.

There was poor understanding of users about the service network, and three interviewed users did not understand the purpose of the work of CAPS, which could explain the low importance given to the proposed appointments. Such situation can be extended if considering twelve people (out of 73) with mental disorders and users of the night shelter for more than three months. Only Antonio reported to have spontaneously sought the CAPS and the UBS (Unidade Básica de Saúde - Primary Health Unit). The night shelter technicians tried to encourage the autonomy and/or family reintegration, but these ideas were rejected by family members and denied by users. Along with that came the concern for institutionalization, verbalized by the technician:

How far do you benefit from the night shelter and how far does it harm you, from the moment that you live in institutionalized? (T2)

\section{DISCUSSION}

Based on the results, follows the analysis of the material generated from the three main categories for the addressed question: access, equity and disaffiliation.

\section{Access}

Difficulty in identifying and accommodating the demands of Mental Health

In this county, the Social Services teams receive support from the Mental Health services, increasing the accessibility by adjusting the social approach to the psychosocial needs of the homeless. However, it is noteworthy that this support is limited to a professional in a period of the day, per week. Other health services, such as the health units (UBS) and the SAMU, often raise questions of various orders that prevent the effective care of people experiencing homelessness and practically exclude the possibility of a care network ${ }^{(17)}$.

The Mental Health services operate in a fragmented manner and with fewer professionals than needed, overloading the Social Assistance sector. The Social Service professionals, which have the social demands as object of intervention added to those of other sectors ${ }^{(9)}$, find themselves forced to perform the user embracement indiscriminately and in isolation, as this remains the only possible alternative to assist the homeless, including those with SMI.

\section{Improper location of social assistance services}

In the reports of workers and users, we perceived the rejection of the population in implementing services of user embracement for people experiencing homelessness in certain districts of the city, a fact that hinders the effectiveness of accessibility by producing ecological obstacles arising from this reaction ${ }^{(18)}$, resulting in inequity in the service use. In addition, as these services are located in regions without leisure options and support of public safety, people are induced to remain inside the night shelter, favoring the institutionalization rather than encouraging autonomy and social inclusion. Both the spontaneous access and the coordination with other services could be facilitated with the adequate geographical accessibility for this population ${ }^{(17)}$, which does not occur in the studied case.

Restricted adaptation of the Mental Health services to the specificities of the clientele

The itinerant population, the difficulties in maintaining relationships and the use of psychoactive substances as a survival strategy in the streets, draw a profile of specificities of the homeless ${ }^{(2)}$. Such profile, in face of the poorly adapted model of health services, results in frequent abandonment of treatment by the clientele.

Apart from the poor infrastructure of the CAPS-AD and CAPS III, especially in relation to the location and the number of professionals available, the low accessibility arising from organizational barriers was identified ${ }^{(17)}$ as a criterion for entering the CAPS-AD or for maintaining nonspecific strategies and poorly adapted to the characteristics of the homeless. As a rule, the considered health services act according to the traditional model of care through spontaneous demand, making social assistance services responsible for the active search of the clientele and their guarantee of access to public services.

\section{Refractoriness of the teams of other services to the homeless clientele}

According to the statements of the interviewed workers, the health teams act as if the homeless did not have other needs besides those related to alcohol abuse, what creates different barriers for assisting this population and reduces their accessibility to the diverse healthcare modalities they need. Thus, a series of ecological (inadequate public transportation, location of services, unestablished interservices and intersectors flow) and organizational barriers (unpreparedness for dealing with specific issues of this clientele) negatively influence the accessibility in the public health network ${ }^{(17)}$. As stated, this set of factors leads the social assistance staff to become solely responsible for ensuring users' access to care in Mental Health. 
This situation strongly illustrates the low degree of collaboration between social services and health services and, consequently, of the intersectoral work, accentuating the process of disaffiliation ${ }^{(19)}$ of the homeless with SMI. These observations are in agreement with a study carried out in Toronto, Canada, indicating a greater perception of discrimination against the homeless with SMI and/or drug use in health facilities ${ }^{(20)}$.

\section{Indefiniteness of the user embracement flow for the homeless with SMI}

There are no formally established flows to assist the homeless with SMI in the network herein addressed, which hinders accessibility, as has been demonstrated. Moreover, the disconnection between the services and sectors makes it difficult for users to understand the duties of each team, and what to require from them in relation to their social and health problems, which may reduce their ability to use the services ${ }^{(17)}$. A similar fact was pointed out by a study with the homeless in Amsterdam, in which half of the surveyed people who reported having health problems did not know how these services could help them, or that they did not know where to look for help ${ }^{(21)}$. If on the one hand the homeless population does not often demand the services of Mental Health, on the other hand, the network does not perform actions that will make customers more informed about their rights. The lack of a treatment protocol is therefore, a cause for confusion and personalization of relationships within the involved teams themselves.

\section{Equity}

\section{Low institutionality of the patient flow between services}

The intersectionality is a consensus in the speeches of the interviewed participants, but there are differences in their operationalization. The effective collaboration between sectors depends on the existence of flows that consider people and their relationships, but that are not restricted to this, in order to ensure a continued and effective organizational functioning. Traditionally, the networks of public policies in Brazil overvalue personal contacts rather than institutional coordination ${ }^{(22)}$, a fact that undermines the sustainability of intersector work in the public network. As we have seen, the absence of standardized flows and collaborations in the attention to the homeless with SMI, and the resistance of the services to assist these clients seems to impose the establishment of interpersonal relationships as an alternative, in order to allow the minimum flow between sectors ${ }^{(23)}$. This personalization of relations, although useful for the execution of some actions, indicates a low degree of institutionalization aimed to ensure equity for an especially vulnerable clientele.

\section{Insufficient human resources}

Besides the lack of established flows, we found the lack of people to run the intersectoral work. Intersectoriality materializes by concrete subjects who carry out the practices ${ }^{(23)}$. The inclusion of only one professional from the Mental Health services in the joint work with the Social Assistance once a week is emblematic of the difficulty to translate into practice the principles of collaboration between sectors, causing serious damage to the notion of equity ${ }^{(18)}$, and preventing investments in intersectoral work.

\section{Antagonisms between the paradigms of the involved sectors}

The contact between the teams of Social Assistance and Public Safety emphasizes the differences between the strategies of these sectors in the work with the people experiencing homelessness. The first searches an effective user embracement and the guarantee of the homeless rights, and the second operates on ensuring the public order, removing the homeless from public places in a deliberate manner and uncoordinated with the sectors of Social Health and Assistance.

At a local level, this situation seems to mirror the discussion about the consequences of a state that minimizes the destiny of resources and interventions on social issues and in contrast, increases penal interventions as a means of maintaining the economic system, suppressing the share of the unproductive population to ensure the security of property and its owners ${ }^{(24)}$. In the studied case, the Social Assistance sector seeks to establish social assistance policies within a disciplinary hegemonic paradigm, portrayed by the exacerbation of Public Safety actions reported here.

In this sense, the recreation of the object to be approached by intersectoral initiatives - since the different points of view will generate new ways of perceiving and operating on the problem, considered by Andrade ${ }^{(10)}$ seems to be something to be reached yet. Because the three sectors considered, Assistance, Health and Safety, still were not able to articulate their perspectives in order to constitute a new and common object of intervention.

\section{Disaffiliation}

The night shelter as a means of insertion in the assistance area

When the night shelter acts as a long-term care institution $^{(5)}$, offering stay for an extended period, it stimulates a daily routine and the generation of feelings of relative safety. Putting people experiencing homelessness in the assistance area ${ }^{(19)}$ offers a greater possibility of social integration, but the situations that discourage autonomy or strongly oppose to the nomadism that can be dear to the homeless, should be avoided ${ }^{(2)}$. An idealized and normative view on the proper path for the homeless must be confronted with the view that considers the specificities of each individual. For some street people, remaining in that situation, eventually using the night shelter and having access to health services, can configure an advance on their quality of life, as in the case of Aline who, after 
discovering her pregnancy, was persuaded to make a more systematic use of both the night shelter as the UBS, within her possibilities and projects. In other words, the path from disaffiliation to the assistance area should be built carefully, so as not to deny options and projects that constitute the life of each person in situation of street in particular. Similar actions were observed in two programs in the United States, which offer coordinated and assisted care of residence and treatment in Mental Health, increasing the use of health services ${ }^{(25)}$.

The concerned clientele would require, in addition to shelter, the simultaneous development of strategies for psychosocial rehabilitation ${ }^{(26)}$, where the theoretical and practical framework allows to extend the possibilities in everyday life of people with SMI by encouraging the acquisition of skills and expanding sociability. For Antônio, the process of psychosocial rehabilitation allowed the acquisition of governmental monthly financial benefit, restoring their autonomy and providing conditions of living alone.

\section{Bonding through the technical team}

The teams of social assistance services operate similarly to the model of team reference used by the Mental Health services. The interdisciplinary work and the bonding were found ${ }^{(27)}$, as well as the investment of workers in the inclusion of a social group that suffers with the stigma of madness ${ }^{(28)}$. Thus, the technicians provide the construction of spaces of sociability different from those where their clientele live, to make bearable an everyday life that, above all, is afflictive ${ }^{(19)}$.

The approach of the social assistance team to people experiencing homelessness in the first contacts on the street, in everyday life in the night shelter, and in accompaniments to other services stimulates the construction of positive bonding. However, the relations among people themselves who live in the night shelters were fragile, and in most cases non-existent. The rotation of people, the situations of violence and the prejudice among people living under the same conditions were identified as barriers to building relationships among them. Thus, it is noted that the connections with other services, other people, and with the society in general are done primarily through the mediation of the technical staff, which can lead to dependence and the deterioration of assistance in welfarism.

\section{REFERENCES}

1. Rosa CMM. Vidas de rua. São Paulo: Hucitec; 2005.

2. Brasil. Ministério da Saúde; Secretaria de Atenção à Saúde, Departamento de Atenção Básica. Manual sobre o cuidado à saúde junto à população em situação de rua. Brasília; 2012.

\section{CONCLUSION}

We identified weaknesses in the public health system of the studied city in relation to the composition of services and the intersector coordination for the user embracement of the homeless with SMI. The social assistance teams significantly expand the access of this population to health services. The requirements made by some services to serve the homeless, such as the existence of a fixed address or presentation in perfect hygienic conditions, are incompatible with this clientele and only highlight the need to search for more explanations on the issues that determine the resistance showed by the professionals working in the mentioned services.

The equity regarding the homeless is compromised by structural reasons, as mirrored by the low number of care workers, but especially in the health area, for the conduction of intra and intersectoral work. With respect to the work process, the little adaptation of the CAPS to the specificities of the homeless is relevant, remaining fixed in a model based on spontaneous demands, increasing the inequity situation of the considered clientele.

It was found that the user embracement in the night shelter enables the protection of the clientele regarding disaffiliation, ensuring social inclusion through contact with the network of public services, with professional teams and with other individuals and users of the considered services. On the other hand, the constancy of the factors that hinder the access of the homeless to Mental Health services in particular, contributes to the social exclusion and to the risk of social disaffiliation.

There is urgent need to strengthen teams of Mental Health and of Social Assistance through continuing education and increasing the number of staff, concomitant to the expansion of understanding by the members of those teams, about the specificities and rights of people experiencing homelessness. The set of initiatives, continuing education, expansion of human resources and understanding of the rights of the homeless clientele, points to the need of developing a technical assistance model that translates to the intersectoral practice the principles of the National Policy for Social Inclusion of the Population in Situation of Street, proposed in 2008. This initiative includes the teams and services considered here, but goes beyond, requiring efforts and convergence of managers from the two sectors considered at municipal, state and federal levels.

3. Brasil. Governo Federal. Política Nacional para Inclusão Social da População em Situação de Rua. Brasília; 2008.

4. Mattos RM. Situação de rua e modernidade: a saída das ruas como processo de criação de novas formas de vida na atualidade [dissertação]. São Paulo: Universidade São Marcos; 2006.
Access, equity and social cohesion: evaluation of intersectoral strategies for people experiencing homelessness Borysow IC, Furtado JP 
5. Brasil. Ministério do Desenvolvimento Social e Combate à Fome; Conselho Nacional da Assistência Social. Resolução no 109, de 11 de novembro de 2009. Aprova a Tipificação Nacional de Serviços Socioassistenciais. Diário Oficial da União (Brasília). 2009;(225):1-43.

6. Brasil. Ministério da Saúde. Portaria n. 122 de 25 de janeiro de 2012. Define as diretrizes de organização e funcionamento das Equipes de Consultório na Rua [Internet]. Brasília; 2012 [citado 2013 dez. 12]. Disponível em: http://bvsms.saude.gov. br/bvs/saudelegis/gm/2012/prt0122_25_01_2012.html

7. Heckert U, Silva JMF. Psicoses esquizofrênicas entre a população de rua. Rev Psiq Clín. 2002;29(1):14-9.

8. Rodriguez A, Bravo MF. Marco general y conceptuacion. In: Aguilar CG. Rehabilitacion psicosocial y tratamiento integral del transtorno mental severo. Madrid: Asociación Española de Neuropsiquiatría; 2003.

9. Monnerati GL, Souza RG. Da Seguridade Social à intersetorialidade: reflexões sobre a integração das políticas sociais no Brasil. Rev. Katálysis. 2011;14(1):41-49.

10. Andrade LOM. A saúde e o dilema da intersetorialidade. São Paulo: Hucitec; 2006.

11. Scheffer G, Silva LG. Saúde mental, intersetorialidade e questão social: um estudo na ótica dos sujeitos. Serv Soc Soc [Internet]. 2014 [citado 2013 out. 4];(118):366-93. Disponível em: http://www.scielo.br/pdf/sssoc/n118/a08n118.pdf

12. Furtado JP, Nakamura E, Generoso CM, Guerra AMC, Campos FB, Tugny $A$. Inserção social e habitação: um caminho para a avaliação da situação de moradia de portadores de transtorno mental grave no Brasil. Interface (Botucatu) [Internet]. 2010 [citado out. 4];14(33):389-400. Disponível em: http://www.scielo.br/pdf/icse/v14n33/a12v14n33.pdf

13. Yin RK. Estudo de caso: planejamento e métodos. 3a ed. Porto Alegre: Bookman; 2005.

14. Gray DE. Pesquisa no mundo real. 2ª ed. Porto Alegre: Penso; 2012.

15. Michelat G. Sobre a utilização da entrevista não-diretiva em Sociologia. In: Thiollent MJM. Crítica metodológica, investigação social e enquete operária. 3a ed. São Paulo: Polis; 1982. p. 191-211.
16. Bardin L. Análise de conteúdo. Lisboa: Edições 70; 2011.

17. Frenk J. Concept and measurement of accessibility. Salud Pública Méx. 1985;27(5):438-53.

18. Vieira-da-Silva LM, Almeida Filho N. Eqüidade em saúde: uma análise crítica de conceitos. Cad Saúde Pública. 2009;25(2):s217-26.

19. Castel R. As metamorfoses da questão social: uma crônica do salário. 9a ed. Petrópolis: Vozes; 2010.

20. Skosireva A, O'Campo P, Zerger S, Chambers C, Gapka S, Stergiopoulos V. Different faces of discrimination: perceived discrimination among homeless adults with mental illness in healthcare settings. BMC Health Serv Res. 2014;14:376.

21. van Laere IR, Wit MA, Klazinga NS. Pathways into homelessness: recently homeless adults problems and service use before and after becoming homeless in Amsterdam. BMC Public Health 2009;9:3.

22. Brehmer LCF, Verdi M. Acolhimento na Atenção Básica: reflexões éticas sobre a Atenção à Saúde dos usuários. Ciênc Saúde Coletiva. 2010;15 Supl 3:3569-78.

23. Junqueira LAP. Intersetorialidade, transetorialidade e redes sociais na saúde. Rev Adm Pública. 2000;34(6):35-45.

24. Wacquant L. Punir os pobres. 2a ed. Rio de Janeiro: Revan; 2003.

25. Fitzpatrick-Lewis D, Ganann R, Krisnaratne S, Ciliska D, Kouyoumdjian F, Hwang SW. Effectiveness of interventions to improve the health and housing status of homeless people: a rapid systematic review. BMC Health Serv Res. 2011;11:638.

26. Amarante P. Saúde mental e atenção psicossocial. Rio de Janeiro: FIOCRUZ; 2011

27. Furtado J, Miranda L. O dispositivo "técnicos de referência" nos equipamentos substitutivos em Saúde Mental e o uso da psicanálise winnicottiana. Rev Latinoam Psicopatol Fundam. 2006;9(3):508-24.

28. Antonacci MH, Kantorski LP, Willrich JQ, Argiles CTL, Coimbra VCC, Bielemann VLM. The structure and flow of the health care network as an instrument of change in psychosocial assistance services. Rev Esc Enferm USP [Internet]. 2013 [cited 2014 Apr 10];47(4):891-8. Available from: http://www.scielo. br/pdf/reeusp/v47n4/en_0080-6234-reeusp-47-4-0891.pdf

\section{Acknowledgement}

We thank Vitor da Costa Borysow for designing the logical model. 